Article

\title{
Digital Social Innovation and Urban Space: A Critical Geography Agenda
}

\author{
Chiara Certomà ${ }^{1,2}$ \\ ${ }^{1}$ Department of Economic and Social Sciences and Mathematics-Statistics, University of Turin, 10124 Turin, Italy; \\ E-Mail: chiara.certoma@ugent.be \\ ${ }^{2}$ Centre for Sustainable Development, Ghent University, 9000 Ghent, Belgium
}

Submitted: 24 May 2020 | Accepted: 21 Jul 2020 | Published: 14 October 2020

\begin{abstract}
Digital Social Innovation (DSI) is a new concept referring to social innovation initiatives that leverage digital technologies potentiality to co-create solutions to a wide range of social needs. These initiatives generally take place in urban contexts. However, in the existing literature, scarce attention is devoted to the spatial dimensions and the social, cultural or political space-related effects of DSI practices. This article suggests that a critical geography perspective can address these gaps. After a review of existing relevant contributes, the article elaborates a research agenda for a critical geography of DSI. This articulates along four research lines, including the emergence of DSI networks, the (re)production of DSI processes and socio-cultural urban space, the representations of DSI practices and the power relationships these mobilise.
\end{abstract}

\section{Keywords}

critical geography; critical Internet studies; digital social innovation; urban space and spatialities

\section{Issue}

This article is part of the issue "The City of Digital Social Innovators" edited by Chiara Certomà (Ghent University, Belgium), Antonella Passani (T6-Ecosystems, Italy) and Mark Dyer (University of Waikato, New Zealand).

(C) 2020 by the author; licensee Cogitatio (Lisbon, Portugal). This article is licensed under a Creative Commons Attribution 4.0 International License (CC BY).

\section{In Search of the Spatial Dimensions of Digital Social Innovation}

The concept of Digital Social Innovation (DSI) emerged in the last 10 years (Caulier-Grice, Davies, Patrick, \& Norman, 2012; Henning \& Hess, 2010) and refers to a:

Type of social and collaborative innovation in which innovators, users and communities collaborate in using digital technologies to co-create knowledge and solutions for a wide range of social needs and at a scale and speed that was unimaginable before the rise of the Internet. (Bria, 2014, p. 9)

As for other innovation experiences, also for DSI, the application context plays a significant role, for instance, in triggering or hampering profitable relationships. The city seems to offer the necessary conditions for experimenting with social innovation and its digital variant, by virtue of its relative spatial compactness, infrastructural and social density, high level of digital connectivity, and cultural diversification that is often accompanied by a propensity to test proposed innovations (Section 2.2). Nevertheless, the multiple spatial dimensions involved in, and implied by DSI processes have been significantly disregarded in the scientific literature, apart from some considerations on the relationship between space and DSI have been advanced in innovation management and regional economic studies (Section 2.2). However, the positivist understanding of space these last provide conflicts with a contextual and relativist appreciation of it.

This article claims that in order to get a more nuanced appreciation of DSI relationship with the fluid, mutable, multiple spaces of contemporary city (Harvey, 2006; Massey, Allen, \& Sarre, 1999) we need to adopt a critical geography perspective (see Section 3).

Nevertheless, at present DSI does not appear amongst critical geography's research interests. To draw potential future research lines, the present article reviewed cognate works on the connections between geography and the digital turn, and the spatial implications of the smart city paradigm (Section 3 ). 
Suggestions from Critical Urban Theory (Brenner, 2009; Marcuse, Imbroscio, Parker, \& Davier, 2014), Science and Technology Studies and Critical Internet Studies (Hunsinger, 2019) have been complementarily considered. Building upon the above-mentioned research, a future agenda is eventually drawn along four lines, including: 1 ) the socio-spatial structures produced by and generating on its turn DSI initiatives (networks); 2) the DSI contribution in perpetuating society and technology relationships in the city ([re]production); 3 ) the space of imaginaries, narratives and visions created by DSI communities (representation); and 4) the entwining of sociopolitical issues brought about by DSI practices (power; Section 4).

\section{DSI and Urban Space}

\subsection{DSI}

In the early 2000s, the digital turn (Westera, 2012) determined a proliferation of web-based processes that granted existing social innovation initiatives (Moulaert, MacCallum, Mehmood, \& Hamdouch, 2013; Moulaert, Martinelli, Swyngedouw, \& Gonzalez, 2005) with the possibility to increase their efficiency, diffusion and effectiveness (Millard \& Carpenter, 2014; Tepsie, 2014). Social innovation processes have been interpreted since the mid19th century (Busacca, 2013) as organisational processes tending toward a more egalitarian society (Léveques, 2001). These processes are labelled as 'social' both in reference to means (i.e., performed through the participation of different actors; Sharra \& Nyssens, 2019) and to ends (i.e., addressing situations which have negative impacts on people's lives and well-being). Their novelty is given by being new to the users, to the context of the application or about the adopted methods (Mulgan, 2006).

In the last 20 years, such an heterogeneous category of initiatives led by civil society tackled issues that States failed to address, and the market had no interest to address; and so re-attracted social scholars' attention (Cajaiba-Santana, 2014; Moulaert et al., 2013; Westley \& McGowan, 2017). The reusing of abandoned buildings (e.g., Refill project), the organisation of new commons (e.g., CommonsTransition, 2020), the realisation of community gardens (Bell et al., 2016), the creation of sharing economy or community currency systems (e.g., Torekes, 2020) can be all considered as forms of social innovation.

Today, digital tools are widely recognised as crucial enablers of social innovation (Maglavera, Niavis, Moutsinas, Passani, \& de Rosa, 2019). However, they do not only trigger, empower, mediate or even transform existing social innovation processes; but also (promise to) innovate the forms and functioning of society whose constitution is deeply pervaded by digital technologies. Therefore, the category of DSI emerged as a novel and distinctive field of practice, compared to the social innovation one (Maglavera et al., 2019; Ozman \& Gossart, 2019; Rodrigo, Palacios, \& Ortiz-Marcos, 2019). It can be defined as an "organisational network model leveraged by information and communication systems" (Rodrigo et al., 2019, p. 64), which relies on "the capacity of civic society to formulate a problem, bring it to the fore of public arenas, and engage a variety of stakeholders to jointly frame and solve this problem" (Ozman \& Gossart, 2019).

The definition of DSI has been elaborated by European digital activists and policy researchers, often (but not exclusively) supported by the European Commission's (henceforth EC) funds (Anania \& Passani, 2014). Up to 2014, DSI initiatives principally gathered under the EC Collective Awareness Platforms for Sustainability and Social Innovation: CAPS (EC, 2020a) umbrella, complementing the market-oriented Digital Agenda for Europe (EC, 2020b) strategy. More recently, in the context of global geopolitical manoeuvres for the leadership of the digital market (Zuboff, 2019), and in consideration of citizens' concerns for ethical implications of ICTs diffusion in private and public life, further than under the pressures of digital activists, the EC decisively characterised its digital development strategy by devoting attention to social concerns. This brought, for instance, to the definition of an ICT-enabled social innovation perspective aimed at boosting communitarian welfare system (Maglavera et al., 2019) and to the funding of the Next Generation Internet (2020) program, which can be regarded as an attempt to advance a distinctive European position in the global panorama dominated by the US vs. China struggle for the dominance of the digital technology market (Internet Governance Project, 2020).

It is against this backdrop that most of the available research on DSI have been produced in the form of grey literature (i.e., reports, position papers, proceedings and policy plans) by EC specialised agencies, department, consultants and project teams (EC, 2020c). EU-funded projects (see the Supplementary File) often propose the pilot applications of new public services and products in local contexts. These include, for instance, the opening of local labs for sharing, repairing or building new devices (e.g., EU projects TESS, EDFx, SISCODE; see the Supplementary File); the life quality enhancement for helping non-autonomous people of single-parents or for assisting patients (e.g., EU projects OPENCARE, WE4AHA, PRONIA); the improvement of environment care, e.g., by lowering individual and groups' carbon emissions (e.g., EU projects CAPTOR, SHELTER, HYPERION); or the boosting of place-based innovations via consultancy and infrastructures provision (e.g., EU projects SI-DRIVE, SIMPACT).

The panorama of DSI initiatives in Europe, however, expands beyond the EC-funded projects (often significantly biased by the willingness to encountering evaluators' consensus; Engelbert et al., 2019). City councils, NGO or CSI organisations, social entrepreneurs (e.g., fablabber, start-upper, social hackers, etc.) independently promoted and self-financed DSI initiatives, covering a wide range of issues (Table 1). 
Table 1. Examples of non-EU-funded DSI projects.

\begin{tabular}{|c|c|}
\hline Issue area & Name of the project \\
\hline $\begin{array}{l}\text { Improvement of civil government } \\
\text { and planning processes }\end{array}$ & $\begin{array}{l}\text { Better Reyjkavik (Iceland), Decide Madrid (Spain), Liquid Democracy (Germany), } \\
\text { Writetothem (UK), Fragdenstaat (Germany) }\end{array}$ \\
\hline $\begin{array}{l}\text { Community cohesion and solidarity } \\
\text { links }\end{array}$ & $\begin{array}{l}\text { Buonacausa (Italy), Spacehive (UK), Freegle (UK), No Lo Tiro (Spain), } \\
\text { Graines de Troc (France) }\end{array}$ \\
\hline Proximity services provision & Peerby (Belgium), Artportalen (Sweden), Nappy Napuri (Finland) \\
\hline Citizens participation in political life & Open Ministry (Finland), Citizen Foundation (UK) \\
\hline Production and working models & $\begin{array}{l}\text { Commons Network (Germany), Edgeryders (Estonia), Future Everything (UK), } \\
\text { ThingsCon (Global), Waag (The Netherlands) }\end{array}$ \\
\hline Technological accessibility & Arduino (Italy), WeProductise (Portugal), CommonFare (Italy) \\
\hline $\begin{array}{l}\text { Personal, social and environmental } \\
\text { care }\end{array}$ & Freecycle (Global), The Impact Lab (Luxembourg) \\
\hline
\end{tabular}

The panorama of DSI initiatives is very dynamic and volatile, however indicative figures signalled that in 2019 the movement of digital social innovators in Europe counts over 2,240 collaboration projects brought forth by about 1,500 organisations (Stokes, Baeck, \& Baker, 2020). These projects combine ideal aspirations with the development of not-for-profit solutions, elaborated through a co-design and co-production approach that distinguishes DSI from digital innovation per se. On this regard, DSI presents affinities with grassroots innovations as it creates opportunities for civic engagement and empowerment (Moulaert et al., 2005). Still, it distinctively does so by bringing together civil society through the use of digital platforms (Ozman \& Gossart, 2019). Therefore, an encompassing formula describes DSI initiatives as "a wide range of projects that use digital technologies, community engagement and collaboration, co-creation strategies and bottom-up approaches to solving societal needs, in opposition to the centralised proprietary solutions owned by a few companies" (Cangiano \& Romano, 2017, p. 3546).

\subsection{Urban Space and Place-Baseness}

The recent popularity of decentralised solutions to social challenges (Hall \& Pfeiffer, 2013; Heynen, 2014) also explains why urban contexts are assumed as the "hotbeds for innovative policy-making and strategies" (Barcelona Activa, 2018). From an institutional perspective, the EC identifies key traits that make the city attractive for testing social innovation, including the diffused small entrepreneurialism, the job-market creativity and the presence of a rich substrate of local skills and culture (JRC, 2020). Not surprisingly, the contemporary city represents the most frequently adopted contexts for the realisation of DSI project (Brandsen, Cattacin, Evers, \& Zimmer,
2016; INEA, 2020; Vandecasteele, Baranzelli, Siragusa, \& Aurambout, 2019) because "when...combined with digital technologies, our urban habitat becomes the most sophisticated technology for interaction ever created" (Han \& Hawken, 2018, p. 2).

However, limited attention has been devoted to the different spatial dimensions (such as the physical, technological, semantic, symbolic and socio-cultural ones) DSI mobilises in the urban assemblages. This lack is likely due to the disciplinary perspective, i.e., the innovation management and regional development approaches (Dacin, Dacin, \& Matear, 2010; Dawson \& Daniel, 2010; Moulaert et al., 2005), that largely dominated research on DSI and the EC policy-making (Rissola, Hervas, Slavcheva, \& Jonkers, 2017) up to now. Specifically, place-baseness stands out as the prominent spatial dimension investigated in management-oriented literature with regard to DSI. It refers to the contextdependent conditions (Eckhardt, Kaletka, \& Pelka, 2018) that are supposed to help the inventive and operational capability of digital social innovators (Boelman \& Heales, 2015; Millard \& Carpenter, 2014, p. 15). This flourishing research stream provides examples of cities considered as perfect ecosystems where the harmonic orchestration of ideas, institutions, regulations and policies feeds the EU smart-specialisation strategy (EU Science Hub, 2020; Whittle, Ochu, \& \& Ferrario, 2012). For instance, the collaboration between the municipality and the Technology Park in Ljubljana that allowed the emergence of startups, co-working spaces, geek houses and hackathons is proposed as a good practice (Bučar \& Rissola, 2018). The impact of such innovation on local development are generally assessed on the base of managerial or economic effects connected with institutional or organisational changes in local institutions' routines and the work culture (Alvord, Brown, \& Letts, 2004; Kaletka \& Pelka, 
2015; Mulgan, 2006; Seyfang \& Smith, 2007; Van der Have \& Rubalcaba, 2016), with no further discussion of the spatial implications.

Analytic research on influential factors that fuel the emergence of DSI has been performed in two EU-funded projects, i.e., DSI4EU and SI-DRIVE. Together with more expectable elements (e.g., dedicated policy measures, resources availability, active citizenry, attractiveness for the creative class, presence of high-level research and education institutions), these suggest that distinctive assets include the presence of 'intractable social problems' that both the public and the market failed to address (Murray, Caulier-Grice, \& Mulgan, 2010); and "the presence of an active civil society endowed with a sufficient level of technological literacy and technology access potential" (SI-DRIVE, 2017). Nevertheless, the final City Index Report (DSI4EU) by Nesta UK concluded that it is:

Simplistic to think [that] the eco-systemic factors and activity should correlate closely....Many DSI initiatives emerge as a response to unfavourable social, political and economic contexts, in an attempt to address social issues that have been overlooked by traditional institutions. Some of the cities which are high-ranking in the index might simply have less need for DSI; and some of the cities which are low-ranking in the index might have conditions which lead people to develop DSI against the odds. (Stokes, 2020)

This leaves, once again, open the issue of the relationship between DSI and urban space, particularly in its sociocultural aspects and suggests the need for a critical geography reflection on DSI.

\section{With the Help of Critical Geography}

The multiple urban spatial dimensions and the spatialities implied, generated or transformed by DSI initiatives have not been adequately considered up to now because the mainstream approach to innovation hampered the possibility for a critical geography appreciation. Critical geography, as a variant of the rich tradition of critical social thinking, is not a coherent epistemology but rather an orientation in geographical research (Murdoch, 2005; Soja, 1989) that embraces political stances to unveil inequalities, injustices and dominations perpetuated through mentalities creation or material forms of coercion (Blomley, 2006); and advances progressist and liberatory claims via the scientific practice.

A critical geography approach to DSI can, thus, foster the exploration of the micro-physical conditions and structures where projects are realised (e.g., a lab, a garage, a square); their social and physical closeness or distance from contexts where similar experiences are performed and from involved communities; the relational proximity to the where tackled problems manifest or from where competences to solve them are made available; the social geography it embeds within; the space of agency conceptualised by involved actors and the symbolic meanings they circulate through the process; the flow of economic resources, competences, and the power that fuel DSI processes; and their impact in terms of people's recognition, empowerment, accessibility and inclusion.

Building upon critical geography tradition (Massey, Allen, \& Sarre, 1999; Merriman et al., 2012), the following pages propose some research streams thought which a future research agenda on DSI space and spatialities (i.e., the relative and relational idea of space produced by social interactions; Amin, 2002; Merriman et al, 2012; Lefebvre, 1974/1991; Sheppard, 2002) can be articulated.

While not explicitly addressing DSI, critical geography contributions on related issues, i.e., the digital turn and the smart city, provide useful feed for thoughts. These signalled that both the concept and the experience of space underwent profound changes in the digital age (Ash, Kitchin, \& Leszczynski, 2018; Cairncross, 1997; Castells, 1996; Friedman, 2005; Harvey, 1989). The digital turn has determined, in fact, an expansion of the urban space by upgrading its material dimensions up to merging with the virtual ones, in single reality-a sort of digital 'hypercity' (Landi, 2019; Massey \& Snyder, 2015). The virtual space of a city can be regarded, thus, just as a continuation of the city around, inside, beyond and behind its physical space, as an 'augmented urban space' (de Cindio \& Aurigi, 2008).

Notably, the diffusion of digital technologies in social life produced dramatic shifts in the production and conception of space, and so it did on spatiality because it produces new spatial relations on multiple layers that can be defined as 'digital spatialities' (Gairola \& Roth, 2019). Digital spatialities are, thus, the effect of the social encounter with space mediated by the digital tools and processes (which increasingly constitute our daily experience of space and its mode of production; Ash, 2009; Sutko \& de Souza e Silva, 2010). These new spatialities have been differently named as code/spaces, hybrid spaces (de Souza e Silva, 2006), digiplace (Zook \& Graham, 2007), net locality (Gordon \& de Souza e Silva, 2011), augmented reality (Graham \& Zook, 2013), mediated spatiality (Leszczynski, 2015), to mention but a few. The diffusion of digital technologies, the interactive web and the Internet of Things has modified the urban hardware and software, i.e., the physical structure and the functional organisation of the digital city (Dyer, Gleeson, \& Grey, 2017). Komninos, Pallot, and Schaffers (2013) identified four main phases of the digital city production. In the first phase, certain activities-reinforcing and amplifying traditional city functions - have been transferred to the web environment and opened to non-experts via the creation of static web pages that provided information about the urban area with text, maps and pictures (Couclelis, 2004, p. 5). The emerge of the interactive web (i.e., the Web 2.0) characterised the second phase. City relationships with the digital have been made 
possible by the diffusion of the ADSL communication bandwidth, the development of Open Source Content Management Systems and the web publishing PHP language (Komninos et al., 2013). As a concequence, the virtual space of the city has been rapidly crowded with collaborative platforms, wikis, blogs, social networking sites, media sharing, hosting of web applications, mashups and similar (Barkat, Jaeggli, \& Dorsaz, 2011). At the end of the 2010s, the third phase has been characterised by the emergence of embedded systems and wireless networks. These made the city metabolism measurable by elaborating data from sensors and interconnected smart devices. Retrieved big data have been made available to citizens via augmented reality applications (Tselentis et al., 2010). Today, the digital city (Mossberger, Tolbert, \& Franko, 2013) relies on "the open data urban system [that] demands open innovation models and people-driven innovation models to turn capabilities offered by data and technologies to services and solutions" (Komninos et al., 2013 , p. 24). The routinely adoption of digital technologies for addressing social problems constitutes a normalisation of previous eccentric practices; and supports the emergence of digital governmentality (Burchell, Gordon, \& Miller, 1991; Dean, 1999; Rajagopal, 2014), whose predictive analytics are used as a new technology for measuring population dynamics; and whose constant incitation to action works as a strategy for impulses and desires control (Barry, 2019).

The digital governmentality, which characterises the technocratic governing of the smart city, has been fiercely criticised by critical geographers (Cardullo, di Feliciantonio, \& Kitchin, 2019; March \& Ribera-Fumaz, 2014; Vanolo, 2013). Together with critical urbanists (Marcuse et al., 2014), these last investigated "how current capitalist organisation shapes processes of sociopolitical, economic and environmental inequalities and deconstruct the discourses underpinning these" (Verrest \& Pfeffer, 2019). In fact, despite the digital revolution was intended to subvert the 19th centuries elites and to redistribute power (Cadwalladr, 2013; Turner, 2006), after a few decades, it produced a power concentration in the hands of a few big companies (notably Google, Facebook, Amazon, Microsoft, Apple), which are able to acquiring patents, engaging hackers and investing in all of the promising Internet of Things and Artificial Intelligence initiatives. Therefore, the digital turn produced its élite and a fracture between those that are in the position to control and modify the codes governing our social (and private) life operations, those who passively use them, and those who have no access at all to the technological devices and the digital infrastructures. The resulting digital divide (van Dijk \& Hacker, 2003) is not limited to the access to technological infrastructures and devices but is also generated by social and cultural barriers (including digital literacy, education, linguistic competences, individual and rights protection; Norris, 2003; Selwyn, 2004; Warschauer, 2004). These conditions produce new geometries of power with their own organisa- tional logics (de Wall, 2015), which can be easily detected in the urban arena. Here the push toward public participation, transparency and openness have been embedded in the smart city programmes and often co-opted by private tech-companies, or by government organisations whose digitalisation plans are heavily conditioned by business companies' investments. An increasing number of critical voices raised to unveil how the corporate storytelling of the hyperconnected city (Söderström, Paasche, \& Klauser, 2014) infiltrates urban planning; and revealed the practical difficulty of negotiating between contrasting public and private interests (Gladwell, 2013; Morozov, 2012; Turkle, 2011).

Although critical geography literature on smart city provides exciting insights, nevertheless this does not specifically refer to DSI. While related, in fact, a smart city does not necessarily host DSI processes, nor the performance of DSI processes is limited to smart city contexts.

\section{A Critical Geography Agenda}

Existing reflections on digital geography and the smart city suggest that critical geography research can provide equally exciting insights when applied to DSI. To this end, multiple geography traditions can be mobilised. Notably, the perspective of Actor-Network-Theory (Latour, 2005; Law, 1995), a transdisciplinary field rooting in Science and Technology Studies, provides a useful standpoint to analyse the social construction and reception of technologies (Bijker, Hughes, \& Pinch, 2012; Hinchliffe, 2008; Whatmore, 2002). Even though it attracted critiques for not embracing the post-structuralist analysis of power relationships (Hetherington \& Lee, 2000; Whittle \& Spicer, 2008), it is an effective explanatory tool in considering how spaces materialise through networked agency (Murdoch, 2005). Radical geography tradition, on the other hand, rooting in the Marxist tradition (Bakker \& Gill, 2003; Katz, 2001; Peet, 1977), offers a standpoint for analysing the societal (re)production practices, particularly in terms of inequalities and the generation of dominant social structures (Hubbard, Kitchin, Bartley, \& Fuller, 2002). Research on socio-spatial representations can be performed by adopting a post-modern critical geography approach (Castree, 2000; Peet, 2000). Representations include narratives, visions and discourses that attribute meaning and values to collective imaginaries; and make thinkable ideas, practices and events untaught (or unthinkable) before. This research stream revolves around the issue of symbolic and material power and its spatial configurations (Crampton \& Elden, 2007). Contributes from Critical Digital Studies (de Rosnay, 2006; Kroker \& Kroker, 2013; Lanier, 2006) can prove equally useful. These include inquires on how digital technologies influence the practice of society and space production, alongside its contestation and transformation against the backdrop of digital geopolitics.

Following the polyvocal vocation of critical geography (Blomley, 2006) research lines proposed below do 
not add up to one framework, but pinpoint aspects along which the space and spatiality of DSI need to be examined in more depth. These research lines aggregate into the following four clusters.

\subsection{Networks, or How Spatial Infrastructures Bring DSI into Existence}

Every DSI initiative can be understood as the emergent effect of a network of networks in which semiotic and material aspects merge. Understanding how these networks interact and create new spaces of social action is crucial to disarticulate the socio-spatial logic of DSI processes (Millard \& Carpenter, 2014). The emergence of a new DSI process is produced by the gathering of a social collective (or 'assemblage') that provide the core innovative technology (i.e., the 'artefact'; MacKenzie \& Wajcman, 1999). In working, testing, improving the artefact (being it a tool-such as an application, a platform or a sensor; or a process-such as a participatory budget or a crowdsourcing algorithm) the collective continuously reframes the problems it is intended to solve into higher-order learning. Each actor of DSI keeps connections and brings along other networks it is already involved in, and therefore makes the boundaries of the system extremely porous and fuzzy. Moreover, a collective's agency generates further networks of higher scale order. These may emerge, for instance, from the relationships amongst similar DSI initiatives (e.g., all the collaborative urbanism digital platforms initiatives); or initiatives financed by the same founder or promoted by the same promoter (e.g., all the DSI initiative funded by the EC); or cognate initiatives happening in the same city or region, aiming the same goal or even adopting a similar set of technologies. How involved actors locate in the physical and social space, and how their interaction connects different sites of knowledge, decision and material production along the DSI processes is still open to investigation.

\subsection{Re-Production, or the Material Production of DSI and the City}

While a prolific research line in critical geography attempted at charting the digital space (Dodge \& Kitchin, 2008), the (bio-)politics of algorithms (Graham, Zook, \& Boulton, 2013; Thrift \& French, 2002), and the critical smart cities (Greenfield, 2017; Kitchin, 2014; Verrest \& Pfeffer, 2019), the (re)production processes of the augmented city remained almost unexplored. DSI initiatives, emerging at the crossroad between the rapid evolution of digital innovations and the cogency of social challenges, clearly show how the transformations of the coded set of procedures that make a city working (i.e., the urban software) can be impacted by different actors. This calls for the consideration of how the social production of space (Lefebvre, 1974/1991) is mediated through the social construction of technologies
(Glimell, 2001), via reproductive processes of the places where DSI processes happen, and "the contentious economic, social, political, and historical contexts of their geographies" (Ash et al., 2018; see also Graham, 2011). A promising research line, therefore, could investigate how DSI processes work as social technologies (Foucault, $1977,1980)$, through the combination of power (i.e., the practices, mechanisms, technologies, etc. that constitute authority) and knowledge (i.e., the forms of thought and expertise used to frame and inform the process of governing).

\subsection{Representations, or the Symbolic Production of DSI and the City Space}

Most of the innovative capacity of DSI communities is primarily exerted in the creation of new visions and narratives, because "rather than [practically] invent a new type of city, the extraordinary array of smart technologies available allow existing spaces to be reconfigured, experienced and imagined in new ways" (Han \& Hawken, 2018 , p. 2). DSI processes are enacted through ad-hoc narratives (e.g., the collective intelligence or enablingtechnology; Turner, 2006), imaginaries (e.g., the Next Generation Internet, or the punk-Internet activism; for the latter see Harris, 2018), and visions (e.g., the smart city, the people friendly city, the resilient city, etc.). The strength of DSI representations roots in two assumptions that made the digital turn possible. Firstly, the positive connotation of direct participation practices in a democratic society, associated with ideals of accessibility, transparency and engagement; second, the 'wisdom of the crowd' (Surowiecki, 2004) mantra, that, apart from some contestations (Lanier, 2006), has had a profound impact in shaping our collective vision of a collaborative society of expert citizens operating through decentralised and connected platforms. Moreover, different social imaginaries hold a connection with various technological tools and contribute to the constitution of urban contexts supporting or impeding progressive changes in society and space. It is through these representations, vehiculated by digital technologies (e.g., web sites, platforms, social networks, federated interned platforms) or even participated via web-based processes (e.g., storytelling and mapping of DSI initiatives) that peoples create spatial attachments. All of these topics represent a vast, only partially explored research domain.

\subsection{Power, or the Entwining of Socio-Political Issues Brought about by DSI Practices}

DSI initiatives are very diverse and roots in opposite worldviews and ideals, directly connected with the political value of adopted technologies (Ash et al., 2018; Sampler, 2019). The described mainstream perspective of management-oriented studies (Section 2) regards DSI as functional to reconfiguring market structures and governance patterns that create services for unanswered so- 
cial demands. According to this approach, both technical and organisational innovations are pursued to facilitate the automation of tasks and to improve the quality and efficiency of business or government processes (Misuraca, Pasi, \& Urzi Brancati, 2017). For instance, the European approach to DSI and the US perspective on the cognate phenomenon of CivicTech, adopt a functionalist perspective but present a different understanding of the role of public and private actors in the governance of urban life. While the first assumes that the economic profit of DSI entrepreneurs is only intended as a side effect of the resolution of a social problem (Nicholls, Simon, \& Gabriel, 2015); the second promotes digital governance processes supported by the private investments of big ICT companies (such as IBM or Microsoft; see Civic Graph Atlas, 2020). Despite the differences, however, both of them align with the neoliberal paradigm of market-led innovation pursued by digital capitalism (Bendiek, Godehardt, \& Shulze, 2019; Internet Governance Project, 2020).

A radically different approach characterises DSI initiatives of digital activists endowed with the intention to radically subvert the existing structure of digitally mediated governance (e.g., Indie.ie or Mastodon project). Such a revolutionary understanding is regarded by many as interpreting the very nature of DSI, whose aim is to change the socio-technological cognitive frames of reference and alter the current social systems, by working outside of the institutional settings (Misuraca et al., 2017). Walking on the edge between reworking or subverting existing institutions, many European DSI communities presented their core values in a short Manifesto for Digital Social Innovation (ChiC, 2020). These include the quest for adoption of open and transparent operational modes that prevent citizens' online activity from being locked into proprietary systems; for decentralised Internet system that promotes citizens' sovereignty over their digital life; and for a sustainable approach to proposed innovation via re-designing Internet governance rules. The Manifesto for Digital Social Innovation (ChiC, 2020 ) is resonant with the Internet activists' proposal of a Shared Digital Europe (Blomen, 2020) and the Universal Declaration of Cyborg Rights (see Ind.ie, 2020). These embrace democratic values and strives for equity and social justice via enabling processes of selfdetermination on private data, cultivation of the (digital) commons, decentralisation of infrastructure and empowerment of public institutions.

Distinguishing between different forms of DSI, while rarely acknowledged, is essential for appreciating how these processes play very diverse roles in the reproduction of (digital) capitalism and the discursive, political and material transformation of urban space.

\section{Prospectives on Space and Spatiality of DSI}

The article builds on the assumption that DSI is a multifaced phenomenon that has not been sufficiently in- vestigated from a critical perspective up to now. Spacerelated aspects have been incidentally addressed by innovation management and regional studies research, but critical geography can help at drawing a more refined future research agenda. To this end, the article briefly reviewed of geographical research on related issues, i.e., the digital turn and the smart city, and-building upon them-elaborated four potential research lines to examine the DSI phenomenon. The suggested agenda starts with the proposal to investigate the DSI processes as networks of networks, whose functioning make apparent the true nature of the urban space augmented by digital connections. The operational networks generate multiple spatialities that call for the analysis of how the city hardware and software are produced and reproduced via digital and social technologies. In this context, research on representations is crucial because it can deconstruct the mainstream positive narrative of the smart hyperconnected city, functional to the (re)production of the digital capitalism. It can reveal whether cities are to be regarded as mere laboratories for experimenting marketled technocratic governance solutions, or as incubators of citizens' critical engagement, which can also detect and defuse the unwanted consequences of the DSI.

A critical reading of the hegemonic logic of the digital turn (Agyemanm, 2015; Cardullo \& Kitchin, 2018), driven by research into the imaginaries and practices of DSI communities, can eventually emerge. Such a critical reading is intended to reveal how DSI processes are produced and circulate in the society, and how they enhance and maintain specific spatial configurations; and under what conditions they work as progressive and emancipatory political gestures. Along this research line, it is possible to investigate how DSI initiatives fuel the transition from a business-led, techno-deterministic city to a socially innovative community-driven one; and how they create technological tools and processes on the base of people's needs-rather than corporates' interests (Calzada \& Cobo, 2015). Therefore, the supposedly progressive, democratic and empowering character of DSI can be problematised at the light of the techno-material practices adopted, their accessibility and effectiveness, their socio-political impacts (e.g., empowerment possibility, room for participation, data and infrastructures ownership and control). Moreover, it can unveil how technological practices associated with DSI initiatives chart discourses, infiltrate material methods in a relational, contingent and contextual way, and how they sustain particular kinds of interests in the society, by also feeding existing geometries of power or creating new ones.

\section{Acknowledgments}

The author acknowledges the research grant Supporting Principal Investigator (SPIN) for the research project “Exploring Digital Social Innovations ecosystems and Urban Governance models in a quadruple helix perspective-DSI4UG" and the Research Institute 
for Social Innovation, Department of Management, Ca'Foscari University of Venice.

\section{Conflict of Interests}

The author declares no conflict of interests.

\section{Supplementary Material}

Supplementary material for this article is available online in the format provided by the author (unedited).

\section{References}

Agyemanm, J. (2015). Sharing Cities: A case for truly smart and sustainable cities. Cambridge, MA: MIT Press.

Alvord, S. H., Brown, L. D., \& Letts, C. W. (2004). Social entrepreneurship and societal transformation: An exploratory study. The Journal of Applied Behavioral Science, 40, 260-282.

Amin, A. (2002). Spatialities of globalisation. Environment and Planning A, 34, 385-399.

Anania, L., \& Passani, A. (2014). A Hitchhiker's guide to digital social innovation. Paper presented at the 20th ITS Biennial Conference, Rio de Janeiro, Brazil.

Ash, J. (2009). Emerging spatialities of the screen: Video games and the reconfiguration of spatial awareness. Environment and Planning $A, 41,2105-2124$.

Ash, J., Kitchin, R., \& Leszczynski, A. (2018). Digital turn, digital geographies? Progress in Human Geography, 42(1), 25-43.

Bakker, I., \& Gill, S. (Eds.). (2003). Power, production, and social reproduction. New York, NY: Palgrave Macmillan.

Barcelona Activa. (2018). Mapping DSI: Cities and urban development. Barcelona: Barcelona Activa. Retrieved from https://digitalsocial.eu/images/upload/ 33-Cities\%20and\%20urban\%20development.pdf

Barkat, H., Jaeggli, L., \& Dorsaz, P. (2011). Citizen 2.0: 17 examples of social media and government innovation: Innovation for social change. Boston, MA: RedCut. Retrieved from http://citizen20.redcut.ch/ Citizen\%202.0\%20(EN).pdf

Barry, L. (2019). The rationality of the digital governmentality. Journal for Cultural Research, 23(4), 365-380.

Bell, S., Fox-Kämper, R., Keshavarz, N., Benson, M., Caputo, S., Noori, S., \& Voigt, A. (Eds.). (2016). Urban allotment gardens in Europe. London: Routledge.

Bendiek, A., Godehardt, N., \& Shulze, D. (2019). The age of digital geopolitics. International Politics and Society. Retrieved from https://www.ips-journal.eu/infocus/chinas-new-power/article/show/the-age-ofdigital-geopolitics-3593

Bijker, W. E., Hughes, T. P., \& Pinch, T. (2012). The social construction of technological systems. Boston, MA: MIT Press.

Blomen, S. (2020). A vision for a shared digital Europe.
Share Digital Europe. Retrieved from https://shareddigital.eu

Blomley, N. (2006). Uncritical critical geography? Progress in Human Geography, 30(1), 87-94.

Boelman, V., \& Heales, C. (2015). Social innovation strategies: Regional report. Brussels: European Commission. Retrieved from http://www.si-drive.eu/wpcontent/uploads/2018/03/D3.6-SI-DRIVE-GlobalRegion-Report-2015.pdf

Brandsen, A., Cattacin, T., Evers, S., \& Zimmer, A. (Eds.). (2016). Social innovations in the urban context. New York, NY: Springer.

Brenner, N. (2009). What is critical urban theory? City, 13(2/3), 198-207.

Bria, F. (2014). Digital social innovation. Brussels: European Commission. Retrieved from https://waag. org/sites/waag/files/media/publicaties/dsi-reportcomplete-Ir.pdf

Bučar, M., \& Rissola, G. (2018). Place-based innovation ecosystems: Ljubljana start-up ecosystem and the Technology Park Ljubljana. European Commission. Retrieved from https://op.europa.eu/en/publicationdetail/-/publication/3e0ebc68-358b-11e9-8d0401aa75ed71a1/language-en

Burchell, G., Gordon, C., \& Miller, P. (Eds.). (1991). The Foucault effect: Studies in governmentality. Chicago, IL: University of Chicago Press.

Busacca, M. (2013). Oltre la retorica della social innovation [Beyond the retoric of social innovation]. Impresa Sociale, 2, 39-55.

Cadwalladr, C. (2013, May 5). Stewart Brand's Whole Earth Catalog, the book that changed the world. The Guardian. Retrieved from https://www.theguardian. com/books/2013/may/05/stewart-brand-wholeearth-catalog

Cairncross, F. (1997). The death of distance. London: Orion Business Books.

Cajaiba-Santana, G. (2014). Social innovation: Moving the field forward. Technological Forecasting and Social Change, 82, 42-51.

Calzada, I., \& Cobo, C. (2015). Unplugging: Deconstructing the smart city. Journal of Urban Technology, 22(1), 23-43.

Cangiano, S., \& Romano, Z. (Eds.). (2017). The growth of digital social innovation in Europe: An open design approach to support innovation for the societal good. The Design Journal, 20.

Cardullo, P., di Feliciantonio, C., \& Kitchin, R. (Eds.). (2019). The right to the smart city. London: Emerald.

Cardullo, P., \& Kitchin, R. (2018). Smart urbanism and smart citizenship: The neoliberal logic of 'citizenfocused' smart cities in Europe. Environment and Planning C: Politics and Space, 37(5), 813-830.

Castells, M. (1996). The rise of the network society. Oxford: Blackwell.

Castree, N. (2000). Professionalisation, activism, and the university: Whither' critical geography'? Environment and Planning A, 32(6), 955-970. 
Caulier-Grice, J., Davies, A., Patrick, R., \& Norman, W. (2012). Defining social innovation. Brussels: European Commission. Retrieved from https:// youngfoundation.org/wp-content/uploads/2012/ 12/TEPSIE.D1.1.Report.DefiningSociallnnovation. Part-1-defining-social-innovation.pdf

ChiC. (2020). Manifesto for digital social innovation. CAPPSI. Retrieved from https://www.dsimanifesto. eu/manifesto

Civic Graph Atlas. (2020). Civic Graph Atlas for civic innovation. Civic Graph Atlas. Retrieved from https://www.govtech.com/data/Microsoft-CivicGraph-Charts-the-New-World-of-Civic-Tech.html

Couclelis, H. (2004). The construction of the digital city. Environment and Planning B, 31, 5-19.

Crampton, J. W., \& Elden, S. (Eds.). (2007). Space, knowledge and power: Foucault and geography. Aldershot: Ashgate.

Dacin, P. A., Dacin, M. T., \& Matear, M. (2010). Social entrepreneurship: Why we don't need a new theory and how we move forward from here. Academy of Management Perspectives, 24(3), 37-57.

Dawson, P. M., \& Daniel, L. (2010). Understanding social innovation: A provisional framework. International Journal of Technology Management, 51(1), 9-12.

de Cindio, F., \& Aurigi, A. (2008). The augmented urban space. London: Routledge.

de Rosnay, M. D. (2006). Alternative policies for alternative Internets. Journal of Peer Production, 9, 1-10.

de Souza e Silva, A. (2006). From cyber to hybrid: Mobile technologies as interfaces of hybrid spaces. Space and Culture, 9, 261-278.

de Wall, M. (2015). The City as interface: How new media are changing the city. Amsterdam: NAI.

Dean, M. (1999). Governmentality: Power and rule in modern society. London: Sage.

Dodge, M., \& Kitchin, R. (2008). Atlas of cyberspace. Kitchin. Retrieved from http://www.kitchin.org/atlas

Dyer, M., Gleeson, D., \& Grey, T. (2017). Framework for collaborative urbanism. In C. Certomà, M. Dyer, L. Pocatilu, \& F. Rizzi (Eds.), Citizen empowerment and innovation in the data-rich city (pp. 57-77). Cham: Springer.

Eckhardt, J., Kaletka, C., \& Pelka, B. (2018). Copy here, paste there? On the challenges of scaling inclusive social innovations. In M. Antona \& C. Stephanidis (Eds.), Universal access in human-computer interaction: Methods, techniques, and best practices (pp. 50-62). New York, NY: Springer.

EU Science Hub. (2020). Smart specialisation. European Commission. Retrieved from https://ec.europa.eu/ $\mathrm{jrc} / \mathrm{en} / \mathrm{research}$-topic/smart-specialisation

European Commission. (2020a). Collective awareness platforms for sustainability and social innovation. European Commission. Retrieved from https:// ec.europa.eu/digital-single-market/en/collectiveawareness-platforms-sustainability-and-socialinnovation
European Commission. (2020b). Digital agenda for Europe. European Commission. Retrieved from https://www.europarl.europa.eu/factsheets/en/ sheet/64/digital-agenda-for-europe

European Commission. (2020c). Next Generation Internet initiative. European Commission. Retrieved from https://ec.europa.eu/digital-single-market/en/ next-generation-Internet-initiative

Foucault, M. (1977). Discipline and punish: The birth of the prison. London: Penguin.

Foucault, M. (1980). The eye of power. In C. Gordon (Ed.), Power/knowledge: Selected writings, 1972-77 (pp. 146-165). New York, NY: Pantheon.

Friedman, T. (2005). The world is flat: A brief history of the twenty-first century. New York, NY: Straus and Giroux.

Gairola, R. K., \& Roth, M. (2019). Cyber zones: Digital spatialities and material realities across Asia. Asiascape: Digital Asia, 6(1/2), 4-16.

Gladwell, M. (2013). David and Goliath, underdogs, misfits, and the art of battling giants. New York, NY: Brown and Company.

Glimell, H. (2001). The social production of technology: On the everyday life with things. Gothenburg: BAS Publisher.

Gordon, E., \& de Souza e Silva, A. (2011). Net locality: Why location matters in a networked world. Chichester: Wiley-Blackwell.

Graham, M. (2011). Time machines and virtual portals: The spatialities of the digital divide. Progress in Development Studies, 11, 211-227.

Graham, M., \& Zook, M. (2013). Augmented realities and uneven geographies: Exploring the geo-linguistic contours of the web. Environment and Planning A, 45, 77-99.

Graham, M., Zook, M., \& Boulton, A. (2013). Augmented reality in the urban environment. Transactions of the IBG, 38, 464-479.

Greenfield, A. (2017). Radical technologies: The design of everyday life. London: Verso.

Hall, P., \& Pfeiffer, U. (2013). Urban future 21. New York, NY: E\&FN Spon.

Han, H., \& Hawken, S. (2018). Introduction: Innovation and identity in next-generation smart cities. City, Culture and Society, 12, 1-4.

Harris, J. (2018, February 1). The punk rock Internet. The Guardian. Retrieved from https://www.theguardian. com/technology/2018/feb/01/punk-rock-Internetdiy-rebels-working-replace-tech-giants-snooperscharter

Harvey, D. (1989). The condition of postmodernity. London: Sage.

Harvey, D. (2006). Space as keyword. In D. Harvey (Ed.), Spaces of global capitalism: Towards a theory of uneven geographical development (pp. 70-93). London: Verso.

Henning, K., \& Hess, F. (2010). Social innovation: Concepts, research field and international trends. Assen: 
ZWE der TU-Dortmund.

Hetherington, K., \& Lee, N. (2000). Social order and the blank figure. Environment and Planning D, 18(2), 169-184.

Heynen, N. (2014). The urban century. Progress in Human Geography, 38(4), 598-604.

Hinchliffe, S. (2008). Geographies of nature: Societies, environments, ecologies. London: Sage.

Hubbard, P., Kitchin, R., Bartley, B., \& Fuller, D. (2002). Thinking geographically: Space, theory and contemporary human geography. London: Continuum Books.

Hunsinger, J. (2019). Critical Internet studies. In J. Hunsinger, M. M. Allen, \& L. Klastrup (Eds.), Second international handbook of Internet research (pp. 263-279). New York, NY: Springer.

Ind.ie. (2020). Universal declaration of cyborg rights. Ind.ie. Retrieved from https://cyborgrights.eu

INEA. (2020). Smart cities and communities. European Commission. Retrieved from https://ec.europa.eu/ inea/en/horizon-2020/smart-cities-communities

Internet Governance Project. (2020). Geopolitics of IG. Internet Governance Project. Retrieved from https://www.Internetgovernance.org/category/ geopolitics-of-ig

JRC. (2020). Cities as innovation hubs. JRC. Retrieved from https://urban.jrc.ec.europa.eu/thefutureof cities/cities-as-innovation-hubs\#the-chapter

Kaletka, C., \& Pelka, B. (2015). Digital social innovation through public Internet access points. In M. Antona \& C. Stephanidis (Eds.), Universal access in humancomputer interaction: Access to today's technologies (pp. 201-212). Springer: Cham.

Katz, C. (2001). Vagabond capitalism and the necessity of social re-production. Antipode, 33(4), 709-778.

Kitchin, R. (2014). Big data and smart urbanism. GeoJournal, 79, 1-14.

Komninos, N., Pallot, M., \& Schaffers, H. (Eds.). (2013). Smart cities and the future Internet in Europe [Special issue]. Journal of Knowledge Economics, 4, 119-134.

Kroker, A., \& Kroker, M. (2013). Critical digital studies: A reader. Toronto: UTP.

Landi, D. (2019). The image of the hyper city. International Journal of Semiotic Law, 32, 533-548.

Lanier, J. (2006). Digital Maoism: The hazards of the new online collectivism. Edge Magazine. Retrieved from https://www.edge.org/conversation/jaron_lanierdigital-maoism-the-hazards-of-the-new-onlinecollectivism

Latour, B. (2005). Reassembling the social. Oxford: Oxford University Press.

Law, J. (1995). Introduction: Monsters, machines and sociotechnical relations. In H. Nowotny \& K. Taschwer (Eds.), The sociology of science (pp. 1-23). London: Edward Elgar.

Lefebvre, H. (1991). The production of space. Oxford: Blackwell. (Original work published 1974)
Leszczynski, A. (2015). Spatial media/tion. Progress in Human Geography, 39, 729-751.

Léveques, B. (2001). Les entreprises d 'économie sociale, plus porteuses d'innovations sociales que les autres? [Social economy enterprises; more social innovating than others?]. Paper presented at the International Conference of CRISES on Social Innovation, Montreal, Canada.

MacKenzie, D., \& Wajcman, J. (Eds.). (1999). The social shaping of technology. Buckingham: Open University Press.

Maglavera, T., Niavis, H., Moutsinas, G., Passani, A., \& de Rosa, S. (2019). Digital transformation for a better society. Brussels: European Commission. Retrieved from https://capssi.eu/wp-content/uploads/ChiC_ D5.2_Digital_Transformation_for_a_better_societywhitepaper.p.pdf

March, H., \& Ribera-Fumaz, R. (2014). Smart contradictions: The politics of making Barcelona a selfsufficient city. European Urban and Regional Studies, 20(4), 816-830.

Marcuse, P., Imbroscio, D., Parker, S., \& Davier, J. (2014). Critical urban theory versus critical urban studies: A review debate. International Journal of Urban and Regional Research, 38(5), 1904-1917.

Massey, D., Allen, J., \& Sarre, P. (Eds.). (1999). Human geography today. Cambridge: Polity.

Massey, J., \& Snyder, B. (2015). The hypercity that occupy built. In J. Geiger (Ed.), Entr'acte: Avant-gardes in performance (pp. 87-103). New York, NY: Palgrave Macmillan.

Merriman, P., Jones, M., Olsson, G., Sheppard, E., Thrift, N., \& Tuan, Y.-F. (2012). Space and spatiality in theory. Dialogues in Human Geography, 2(1), 3-22.

Millard, J., \& Carpenter, G. (2014). Digital technology in social innovation. Brussels: European Commission. Retrieved from http://www.transitsocialinnovation. eu/content/original/Book\%20covers/Local\% 20PDFs/124\%20TEPSIE\%20synopsis\%20digital\% 20technology\%20in\%20SI.pdf

Misuraca, G., Pasi, G., \& Urzi Brancati, C. (2017). ICTEnabled social innovation: Evidence and prospective. Ispra: JRC. Retrieved from https://publications. jrc.ec.europa.eu/repository/bitstream/JRC108517/ kjna28814enn.pdf

Morozov, E. (2012). In the net delusion: How not to liberate the world. London: Penguin.

Mossberger, K., Tolbert, C., \& Franko, W. (2013). Digital cities: The Internet and the geography of opportunity. Oxford: Oxford University Press.

Moulaert, F., MacCallum, D., Mehmood, A., \& Hamdouch, A. (2013). International handbook of social innovation. Cheltenham: Edward Elgar.

Moulaert, F., Martinelli, F., Swyngedouw, E., \& Gonzalez, S. (2005). Towards alternative model(s) of local innovation. Urban Studies, 42, 1969-1990.

Mulgan, G. (2006). The process of social innovation. Innovations, 1, 145-162. 
Murdoch, J. (2005). Post-structuralist geography. London: SAGE.

Murray, R., Caulier-Grice, J., \& Mulgan, G. (2010). The open book of social innovation. Nesta. Retrieved from https://www.nesta.org.uk/report/theopen-book-of-social-innovation

Nicholls, A., Simon, J., \& Gabriel, M. (2015). Dimensions of social innovation. London: Palgrave Macmillan.

Norris, P. (2003). Preaching to the converted? Pluralism, participation and party websites. Party Politics, 9(1), 21-45.

Ozman, M., \& Gossart, C. (2019). Digital social innovation: Exploring an emerging field. SSRN. http://dx.doi. org/10.2139/ssrn.3434363

Peet, R. (1977). Radical geography: Alternative viewpoints on contemporary social issues. Chicago, IL: Maaroufa Press.

Peet, R. (2000). Celebrating thirty years of radical geography. Environment and Planning A, 32(6), 951-953.

Rajagopal, I. (2014). Does the Internet shape a disciplinary society? The information-knowledge paradox. First Monday, 19(3).

Rissola, G., Hervas, F., Slavcheva, M., \& Jonkers, K. (2017). Place-based innovation ecosystems: Espoo innovation garden and Aalto University. European Union. Retrieved from https://op.europa.eu/en/ publication-detail/-/publication/141a3f98-1e7911e7-aeb3-01aa75ed71a1/language-en

Rodrigo, L., Palacios, M., \& Ortiz-Marcos, I. (2019). Digital social innovation: Analysis of the conceptualization process and definition proposal. Direccion e Organizacion, 67, 59-66.

Sampler, I. (2019, November 24). Tim Berners-Lee unveils global plan to save the web. The Guardian. Retrieved from https://www.theguardian.com/ technology/2019/nov/24/tim-berners-lee-unveilsglobal-plan-to-save-the-Internet

Selwyn, N. (2004). Reconsidering political and popular understandings of the digital divide. New Media \& Society, 6(3), 341-362.

Seyfang, G., \& Smith, A. (2007). Grassroots innovations for sustainable development: Towards a new research and policy agenda. Environmental Politics, 16, 584-603.

Sharra, R., \& Nyssens, M. (2019). Social innovation: An interdisciplinary and critical review of the concept. Mafiadoc. Retrieved from https://mafiadoc. com/social-innovation-literature3_5c685905097c 4706578b4619.html

Sheppard, E. (2002). The spaces and times of globalisation: place, scale, networks and positionality. Economic Geography,78 (3), 307-330.

SI-DRIVE. (2017). Towards a general theory and typology of social innovation. Brussels: European Commission. Retrieved from http://www.si-drive.eu/wpcontent/uploads/2018/01/SI-DRIVE-DeliverableD1_6-Theory-Report-2017-final-20180131.pdf

Söderström, O., Paasche, T., \& Klauser, F. (2014). Smart cities as corporate storytelling. City, 18(3), 307-320.

Soja, E. (1989). Postmodern geographies: The reassertion of space in critical social theory. London: Verso Press.

Stokes, M. (2020). What system factors help DSI to grow and thrive? Digital Social. Retrieved from https://digitalsocial.eu/blog/145/a-first-run-of-thedsi-index

Stokes, M., Baeck, P., \& Baker, T. (2020). What's next for digital social innovation? Nesta. Retrieved from https://www.nesta.org.uk/report/what-next-fordigital-social-innovation-realising-the-potential-ofpeople-and-technology-to-tackle-social-challenges

Surowiecki, J. (2004). The wisdom of crowd. New York, NY: Anchor.

Sutko, D., \& de Souza e Silva, A. (2010). Location-aware mobile media and urban sociability. New Media \& Society, 13, 807-823.

Tepsie. (2014). Social innovation theory and research: A guide for researchers. Brussels: European Commission. Retrieved from https://iupe.files.wordpress. com/2015/11/tepsie-research_report_final_web.pdf

Thrift, N., \& French, S. (2002). The automatic production of space. Transactions of the IBG, 27, 309-335.

Tselentis, G., Galis, A., Gavras, A., Krco, S., Lotz, V., Simperl, E., .. . Zahariadis, T. (Eds). (2010). Towards the future Internet: Emerging trends from European research. Amsterdam: IOS Press.

Turkle, S. (2011). Alone together: Why we expect more from technology and less from each other. New York, NY: Basic Books.

Turner, F. (2006). From counterculture to cyberculture. Chicago, IL: University of Chicago.

Van der Have, R. P., \& Rubalcaba, L. (2016). Social innovation research: An emerging area of innovation studies? Research Policy, 45(9), 1923-1935.

van Dijk, J. A. G. M., \& Hacker, K. (2003). The digital divide as a complex and dynamic phenomenon. Information Society, 19(4), 315-326.

Vandecasteele, I., Baranzelli, C., Siragusa, A., \& Aurambout, J. (2019). The future of cities: Opportunities, challenges and the way forward. European Commission. Retrieved from https://ec.europa.eu/ jrc/en/facts4eufuture/future-of-cities

Vanolo, A. (2013). Smartmentality: The smart city as disciplinary strategy. Urban Studies, 51, 883-898.

Verrest, H., \& Pfeffer, K. (2019). Elaborating the urbanism in smart urbanism: Distilling relevant dimensions for a comprehensive analysis of Smart City approaches. Information, Communication and Society, 22(9), 1328-1342.

Warschauer, M. (2004). Rethinking the digital divide. Cambridge, MA: MIT Press.

Westera, W. (2012). The digital turn: How the Internet transforms our existence. Bloomington, IN: AuthorHouse. Retrieved from http://www.thedigitalturn.co. uk/TheDigitalTurn.pdf

Westley, F., \& McGowan, K. (2017). The evolution of 
social innovation: Building resilience through transitions. Cheltenham: Edward Elgar Publishing.

Whatmore, S. (2002). Hybrid geography. London: Sage Publications.

Whittle, A., \& Spicer, A. (2008). Is actor-network theory critique? Organisation Studies, 29(4), 611-629.

Whittle, J., Ochu, E., \& Ferrario, M. A. (2012). Beyond research in the wild: Citizen-led research as a model for innovation in the digital economy. Paper presented at the Digital Futures 2012 Conference, Aberdeen,
UK. Retrieved from https://www.academia.edu/ 3297686/Beyond_research_in_the_wild_Citizenled_research_as_a_model_for_innovation_in_the_ Digital_Economy

Zook, M. A., \& Graham, M. (2007). Mapping digiplace: Geocoded Internet data and the representation of place. Environment and Planning B, 34, 466-482.

Zuboff, S. (2019). The age of surveillance capitalism: The fight for a human future at the new frontier of power. New York, NY: PublicAffairs.

\section{About the Author}

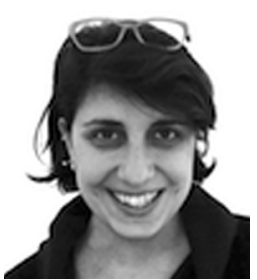

Chiara Certomà is an Assistant Professor in Political-Economic Geography at the University of Turin, Affiliate Researcher at Ghent University and Honorary Research Associate at The University of Waikato. Her interests focus on innovative modes of urban governance and planning in the face of pressing environmental challenges and the digital turn. Information about her research projects and publications can be find at https://crowdusg.net 